\title{
FAKTOR-FAKTOR YANG MEMPENGARUHI KEPUTUSAN PENGAMBILAN KREDIT PADA PT. PEGADAIAN (Studi pada PT. Pegadaian (Persero) Cabang Singaraja Tahun 2017)
}

\author{
Gusti Ayu Eka Tirta Dewi ${ }^{1}$, I Nyoman Sujana², Made Ary Meitriana ${ }^{3}$ \\ Jurusan Pendidikan Ekonomi \\ Universitas Pendidikan Ganesha \\ Singaraja, Indonesia

\begin{abstract}
email : qustiayueka97@gmail.com ${ }^{1}$, nyoman.suiana@undiksha.ac.id², ary.meitriana@undiksha.ac.id ${ }^{3}$
\end{abstract}

\begin{abstract}
Abstrak
Penelitian ini bertujuan untuk mengetahui faktor-faktor yang mempengaruhi keputusan pengambilan kredit dan faktor yang paling dominan dalam mempengaruhi keputusan pengambilan kredit pada PT. Pegadaian Cabang Singaraja tahun 2017. Jenis penelitian ini adalah penelitian faktorial. Populasi dalam penelitian ini adalah seluruh nasabah PT. Pegadaian Cabang Singaraja sebanyak 14.592 orang nasabah, dengan sampel sebanyak 99 responden. Teknik pengambilan sampel dalam penelitian ini menggunakan probability sampling dengan metode proportional random sampling. Pengumpulan data menggunakan kuesioner dan dokumentasi. Data dianalisis dengan analisis faktor melalui program SPSS 16.0. Hasil penelitian menunjukkan bahwa terdapat empat faktor yang mempengaruhi keputusan pengambilan kredit pada PT. Pegadain Cabang Singaraja, yaitu faktor lingkungan sebesar $45,424 \%$, faktor organisasi sebesar $30,664 \%$, dan faktor antar-pribadi sebesar $23,912 \%$. Faktor lingkungan menjadi faktor yang paling dominan karena memiliki variance explained tertinggi sebesar $45,424 \%$, artinya faktor lingkungan mampu menjelaskan keputusan pengambilan kredit pada PT. Pegadaian Cabang Singaraja sebesar $45,424 \%$.
\end{abstract}

Kata kunci: keputusan pengambilan kredit, analisis faktor

\begin{abstract}
This study aimed to investigate factors which influence credit taking decision and factor which is very dominant which influence credit taking decision at PT. Pegadaian Singaraja Unit year 2017. This study used factorial design. The population in this study is all 14.592 customers of PT. Pegadaian Singaraja Unit and the samples are 99 respondents. This study used probability sampling, especially proportional random sampling. The data was collected by using questionnaire and documentation. The data were analyzed by using SPSS 16.0. The result showed that there were 4 factors which influence credit taking decision at PT. Pegadaian Singaraja Unit such as: enviromental factor $45,424 \%$, organizational factor $30,664 \%$, and interperonal factor $23,912 \%$. Enviromental factor was categorized as the most dominant factor because the value of variance explained was $45,424 \%$ which meant enviromental factor was able to display credit taking decision at PT. Pegadaian Singaraja Unit with value $45,424 \%$.
\end{abstract}

Keyword: credit taking decision, factor analysis 


\section{PENDAHULUAN}

Keputusan yang diambil oleh seseorang dapat disebut sebagai sebuah pemecahan masalah (Setiadi, 2003). Dalam proses pengambilan keputusan, konsumen memiliki sasaran atau perilaku yang ingin dicapai atau dipuaskan. Selanjutnya, konsumen membuat keputusan mengenai perilaku yang ingin dilakukan untuk dapat memecahkan masalahnya. Menurut Umar (2003:103), keputusan merupakan hasil proses pemikiran berupa pemilihan satu dari beberapa alternatif yang dapat dipakai untuk memecahkan masalah yang dihadapi. Dengan kata lain untuk membuat keputusan harus terdapat alternatif pilihan. Sebaliknya jika konsumen tidak memiliki alternatif untuk memilih maka tidak dapat dikategorikan sebagai pengambilan keputusan.

Menurut Siagian (dalam Umar, 2003:104), pada hakikatnya pengambilan keputusan merupakan suatu pendekatan sistematis terhadap hakikat suatu masalah, pengumpulan fakta-fakta, dan penentuan yang matang dari alternatif yang dihadapi serta pengambilan tindakan yang menurut perhitungan merupakan tindakan tepat. Pengertian yang lain, "pengambilan keputusan ialah proses memilih suatu alternatif cara bertindak dengan metode yang efisien sesuai situasi" (Setiadi, 2008: 17). Keputusan pengambilan kredit dilakukan oleh masyarakat untuk memecahkan masalah dalam bidang ekonomi. Salah satu tujuannya yaitu untuk mengembangkan usaha, atau modal usaha. Untuk dapat memutuskan mengambil kredit tentunya masyarakat akan mempertimbangkan beberapa faktor-faktor yang akan digunakan untuk mengambil kredit serta menjadi nasabah perusahaan sebagai sumber dana.

Menurut Kotler (2005:244), faktorfaktor yang mempengaruhi keputusan konsumen dalam mengambil kredit diantaranya yaitu lingkungan, organisasi, dan antar-pribadi.

Faktor lingkungan adalah faktor yang diberikan perhatian khusus oleh nasabah. Hal tersebut disebabkan karena faktor lingkungan menyangkut tentang keadaan ekonomi masyarakat yang sedang berlangsung dan yang akan berlangsung, adapun yang menjadi indikator dari faktor lingkungan yaitu tingkat permintaan, tingkat bunga, tingkat perubahan teknologi, perkembangan politik dan peraturan, perkembangan persaingan, dan perhatian pada tanggung jawab sosial.

Faktor organisasi adalah pengaruh yang penting terhadap perilaku yang etis dengan adanya norma, nilai tim, departemen, dan organisasi secara keseluruhan. Riset menunjukkan bahwa nilai-nilai ini sangat memengaruhi tindakan dan proses pengambilan keputusan oleh konsumen. Secara khusus, budaya perusahaan memungkinkan karyawan tahu keyakinan dan perilaku seperti apa yang didukung oleh perusahaan dan seperti apa yang tidak dapat ditoleransi. Setiap organisasi memiliki tujuan, kebijakan, prosedur, struktur organisasi, dan sistem yang spesifik. Konsumen dalam hal ini mempunyai kesempatan untuk memilih organisasi atau perusahaan yang tentunya dapat memenuhi keperluannya dalam hal pendanaan. Maka dari itu organisasi sangat berperan penting dalam menentukan keputusan konsumen untuk mengambil kredit. Adapaun yang menjadi indikator dari faktor organisasi yaitu tujuan, kebijakan, prosedur, dan budaya.

Faktor antar-pribadi dapat diartikan sebagai pengaruh keputusan konsumen yang diakibatkan dari satu individu dengan individu lain untuk mememutuskan mengambil kredit. Setiap konsumen biasanya memiliki keinginan dan kebutuhan yang berbeda-beda. Para kreditur cenderung tidak mengetahui dinamika kelompok seperti apa yang muncul selama proses keputusan pembelian, walaupun semua informasi yang dapat ditemukannya tentang faktor antar-pribadi akan bermanfaat. Adapun yang menjadi indikator dari faktor antar-pribadi yaitu minat, wewenang, empati, dan daya bujuk.

$$
\text { Beberapa hasil penelitian }
$$

sebelumnya menyimpulkan bahwa faktorfaktor yang mempengaruhi keputusan nasabah dalam mengambil kredit pada PT. Finansia Multi Finance (Kredit Plus) Pos Singaraja yaitu faktor produk, faktor proses, faktor bukti fisik, faktor kehandalan, dan faktor jaminan. Sedangkan faktor yang paling dominan mempengaruhi keputusan 
nasabah dalam mengambil kredit pada PT. Finansia Multi Finance yaitu faktor produk dengan varian sebesar $32,846 \%$ (Yasa, 2015). Selain itu menurut Suarni (2014), faktor yang mempengaruhi keputusan nasabah dalam mengambil kredit pada LPD Desa Pakraman Manggissari adalah faktor kebudayaan, faktor sosial, faktor psikologis, dan faktor pribadi. Faktor yang paling dominan mempengaruhi keputusan nasabah dalam mengambil kredit pada LPD Desa Pakraman Manggissari yaitu faktor kebudayaan dengan varimax rotation $53,646 \%$.

PT. Pegadaian merupakan salah satu lembaga keuangan nonbank yang melakukan pembiayaan dalam bentuk penyaluran dana ke masyarakat atas dasar hukum gadai. Tugas pokoknya adalah memberikan pinjaman kepada masyarakat atas dasar hukum gadai agar masyarakat tidak dirugikan oleh kegiatan lembaga keuangan nonformal yang cenderung memanfaatkan kebutuhan dana mendesak dari masyarakat. Manfaat utama yang diperoleh nasabah apabila meminjam di PT. Pegadaian adalah ketersediaan dana dengan prosedur yang relatif lebih sederhana dan dalam waktu yang lebih cepat terutama apabila dibandingkan dengan kredit perbankan lainnya. Selain itu, manfaat dari PT. Pegadaian antara lain: sebagai tambahan dana untuk modal usaha, penaksiran nilai suatu barang bergerak dari pihak atau institusi yang telah berpengalaman dan dapat dipercaya, serta penitipan suatu barang bergerak pada tempat yang aman dan dipercaya.

Berdasarkan hasil observasi awal, penulis mendapatkan informasi mengenai laporan portofolio kredit harian PT. Pegadaian Cabang Singaraja terus mengalami peningkatan di setiap tahunnya. Hal tersebut dapat dilihat dari laporan portofolio kredit harian tahun 2015 sampai dengan 2017. Jumlah kredit aktif di tahun 2015 sebanyak 12.832 nasabah, dengan rincian diantaranya yaitu Produk Kreasi sebanyak 287 nasabah, Produk Mulia Baru sebanyak 50 nasabah, Produk Krasida sebanyak 58 nasabah, Produk Gadai KCA sebanyak 12.435 nasabah, Produk Mulia sebanyak 1 nasabah, dan Produk Kresna sebanyak 1 nasabah. Jumlah kredit aktif di tahun 2016 sebanyak 14.180 nasabah, dengan rincian diantaranya yaitu Produk Kreasi sebanyak 234 nasabah, Produk Gadai Flexi sebanyak 84 nasabah, Produk Emasku sebanyak 142 nasabah, Produk Mulia Baru sebanyak 66 nasabah, Produk Krasida sebanyak 90 nasabah, dan Produk Gadai KCA sebanyak 13.564 nasabah. Jumlah kredit aktif di tahun 2017 sebanyak 14.592 nasabah, dengan rincian diantaranya yaitu Produk Kreasi sebanyak 234 nasabah, Produk Gadai Flexi sebanyak 162 nasabah, Produk Emasku sebanyak 126 nasabah, Produk Krasida sebanyak 150 nasabah, dan Produk Gadai KCA sebanyak 13.920 nasabah. Jumlah nasabah yang berada di PT. Pegadaian Cabang Singaraja diperoleh dari hasil akumulasi 11 unit PT. Pegadaian yang ada di Kabupaten Buleleng.

Pada penelitian ini, penulis ingin mengetahui faktor-faktor apa saja yang mempengaruhi keputusan nasabah mengambil kredit pada PT. Pegadaian serta mengapa masayarakat tidak mengambil kredit di lembaga keuangan lainnya.

\section{METODE}

Berdasarkan rumusan masalah penelitian, kajian teori yang telah dilakukan dan output yang ingin dicapai pada penelitian ini, maka dalam penelitian ini menggunakan rancangan penelitian faktorial. Menurut Suliyanto (2005), analisis faktor adalah suatu teknik yang digunakan untuk menganalisis tentang saling ketergantungan (interindependence) dari beberapa variabel secara simultan menjadi sejumlah faktor yang lebih sedikit dari variabel yang diteliti. Menurut Sarwono (2010:148), analisis faktor digunakan untuk mengidentifikasi variabel-variabel atau faktor-faktor yang menerangkan pola hubungan dalam seperangkat variabel. Teknik ini digunakan untuk mengurangi jumlah data dalam rangka untuk mengidentifikasi sebagian kecil faktor yang dapat menerangkan varians yang sedang diteliti secara lebih jelas dalam suatu kelompok variabel yang jumlahnya lebih besar. Adapun yang menjadi variabel dalam penelitian ini adalah keputusan pengambilan kredit pada PT. Pegadaian Cabang Singaraja, dimensi variabel dalam 
penelitian ini yaitu faktor lingkungan, faktor organisasi, dan faktor antar-pribadi.

Jenis dan sumber data dalam penelitian ini adalah sebagai berikut. Jenis data yang diperlukan dalam penelitian ini adalah data kuantitatif. Data kuantitatif merupakan data yang dihasilkan berupa angka-angka, skor atau nilai, atau pernyataan yang diungkapkan dan dianalisis dengan analisis statistik. Sumber data dalam penelitian ini adalah data primer dan data sekunder. Menurut Indriantoro \& Supomo, (2009:146), data primer merupakan sumber data penelitian yang diperoleh secara langsung dari sumber asli (tidak melalui media perantara). Dalam penelitian ini data primer berupa informasi yang diperoleh dari hasil angket yang disebarkan terhadap nasabah PT. Pegadaian Cabang Singaraja yang menjadi responden terpilih. Sedangkan data sekunder merupakan sumber data penelitian yang diperoleh peneliti secara tidak langsung melalui media perantara (diperoleh dan dicatat oleh pihak lain). Data sekunder dalam penelitian ini adalah berupa dokumen-dokumen pendukung penelitian berupa data jumlah nasabah PT. Pegadaian Cabang Singaraja.

Populasi merupakan suatu wilayah generalisasi yang terdiri atas objek dan subjek yang mempunyai kualitas dan karakteristik tertentu yang ditetapkan oleh peneliti untuk dipelajari dan kemudian ditarik kesimpulan (Sugiyono, 2014). Populasi dalam penelitian ini adalah seluruh nasabah PT. Pegadaian Cabang Singaraja tahun 2017 sebanyak 14.592 orang nasabah. Sampel adalah bagian kecil dari anggota populasi yang diambil menurut prosedur tertentu sehingga dapat mewakili populasinya, teknik pengambilan sampel dalam penelitian ini menggunakan teknik (sampel probabilita) yaitu proportional random sampling. Probability sampling adalah suatu teknik penarikan sampel yang mendasarkan diri bahwa setiap anggota populasi memiliki kesempatan yang sama untuk dipilih sebagai sampel (dalam Prasetyo \& Lina, 2016:118). Adapun langkah-langkah dalam penentuan sampel adalah sebagai berikut. Pertama, penentuan jumlah sampel, jumlah sampel dalam penelitian ini adalah produk kreasi sebanyak 234 nasabah, produk gadai flexi sebanyak 162 nasabah, produk emasku sebanyak 126 nasabah, produk krasida sebanyak 150 nasabah, produk gadai KCA sebanyak 13.920 nasabah. Kedua, perhitungan rumus solvin, menurut Slovin (dalam Umar, 2005:79) untuk menentukan ukuran sampel, minimal dalam suatu proses dilakukan dengan rumus sebagai berikut.

Rumus :
$n=\frac{N}{1+N e^{2}}$

Keterangan:

$\mathrm{n}=$ ukuran sampel

$\mathrm{N}=$ ukuran populasi

$\mathrm{e}=$ error level (tingkat kesalahan atau diinginkan masih dapat ditolerir)

$\mathrm{n}=14.592 / 1+14.592(0,1)^{2}$

$\mathrm{n}=14.592 / 146,92$

$\mathrm{n}=99.319$ (dibulatkan menjadi 99)

Untuk menentukan besarnya sampel pada setiap produk dilakukan dengan alokasi proporsional random sampling (Prasetyo \& Lina, 2016:130) dengan rumus sebagai berikut.

Rumus :

sampel $=\frac{\text { populasi }}{\text { total populasi }} \times$ total sampel

Adapun rincian sampel dalam penelitian ini dapat dilihat pada tabel 1.

Tabel 1. Jumlah Sampel Nasabah PT. Pegadaian Cabang Singaraja

\begin{tabular}{|c|c|c|c|c|}
\hline No. & Nama Produk & $\begin{array}{l}\text { Jumlah } \\
\text { Nasabah }\end{array}$ & Perhitungan & $\begin{array}{l}\text { Jumlah } \\
\text { sampel }\end{array}$ \\
\hline 1. & Produk Kreasi & 234 & $234 / 14.592 \times 99=1,587$ & 2 \\
\hline 2. & Produk Gadai Flexi & 162 & $162 / 14.592 \times 99=1,099$ & 1 \\
\hline 3. & Produk Emasku & 126 & $126 / 14.592 \times 99=0,854$ & 1 \\
\hline 4. & Produk Krasida & 150 & $150 / 14.592 \times 99=1,017$ & 1 \\
\hline 5. & Produk Gadai KCA & 13.920 & $\begin{array}{r}13.920 \times 99 / 14.592=94,441 \\
\text { Total }\end{array}$ & $\begin{array}{l}94 \\
99\end{array}$ \\
\hline
\end{tabular}


Metode pengumpulan data yang digunakan dalam penelitian yaitu sebagai berikut. Kuesioner (angket), yaitu cara pengumpulan data dengan memberikan beberapa pertanyaan yang terkait dengan indikator-indikator yang menjadi variabel penelitian kepada responden (nasabah di PT. Pegadaian Cabang Singaraja). Dokumentasi, yaitu data yang didapatkan dari dokumen-dokumen yang ada dalam perusahaan. Data yang dimaksud adalah jumlah nasabah pada PT. Pegadaian Cabang Singaraja. Kategori penskoran kuesioner faktor-faktor yang mempengaruhi keputusan pengambilan kredit pada PT. Pegadaian Cabang Singaraja dengan skala likert. Skala likert dalam penelitian ini menggunakan lima alternatif jawaban masing-masing diberi skor, yaitu skor 5 =sangat setuju (SS), skor $4=\operatorname{setuju~(S),~}$ skor $3=$ netral $(\mathrm{N})$, skor $2=$ tidak setuju (TS), dan skor 1 = sangat tidak setuju (STS).

Pengujian instrumen penelitian ini menggunakan uji validitas dan reliabilitas. Uji validitas merujuk kepada sejauh mana instrumen dapat digunakan untuk mengukur apa yang hendak diukur, sedangkan uji reliabilitas merujuk pada sejauh mana instrumen pengukur dapat dipercaya atau diandalkan (Sugiyono, 2014).

Menurut Umar (2005:133) untuk menguji tingkat validitas instrumen digunakan teknik analisis Koefisien Korelasi Product Moment Pearson dengan ketentuan nilai $r_{\text {hitung }}>$ dari $r_{\text {tabel }}$ dengan jumlah tingkat kesalahan alpha 0,05. Pengujian reliabilitas instrumen dalam penelitian ini akan dilakukan dengan menggunakan rumus Cronbach's Alpha (Umar, 2005). Instrumen dikatakan reliabel apabila memiliki nilai Cronbach's Alpha lebih besar dari 0,60.

Teknik analisis data yang digunakan dalam penelitian ini yaitu analisis faktor. Menurut Sarwono (2010:148), "analisis faktor digunakan untuk mengidentifikasi variabel-variabel atau faktor-faktor yang menerangkan pola hubungan dalam seperangkat variabel. Teknik ini digunakan untuk mengurangi jumlah data dalam rangka untuk mengidentifikasi sebagian kecil faktor yang dapat menerangkan varians yang sedang diteliti secara lebih jelas dalam suatu kelompok variabel yang jumlahnya lebih besar". Menurut Suliyanto (dalam Yasa, 2015:38), analisis faktor adalah suatu teknik untuk menganalisis tentang saling ketergantungan (independence) dari beberapa veriabel secara simultan dengan tujuan untuk menyederhanakan dari bentuk hubungan antara beberapa variabel yang diteliti menjadi sejumlah faktor yang lebih sedikit dari variabel yang diteliti. Data yang digunakan dalam analisis faktor, minimal data yang berbentuk interval dan data yang diperoleh melalui instrumen kuesioner masih berupa data ordinal. Oleh sebab itu, data ordinal tersebut perlu ditingkatkan skala pengukurannya menjadi skala interval melalui Method of Successive Interval (MSI) dengan bantuan Microsoft Office Excel. Analisis faktor terdiri dari beberapa tahap (Suliyanto, 2005), yaitu :

Pertama, merumuskan masalah merupakan langkah awal dalam analisis faktor. Hal ini dilakukan dengan cara menentukan jumlah variabel yang akan diteliti. Dilihat pula kelengkapan jawaban yang didapat dari kuesioner yang sudah disebarkan. Kemudian merubah data ordinal ke data interval. Data yang didapat dari kuisioner masih berupa data ordinal sedangkan analisis data yang digunakan untuk membuktikan kebenaran pengujian analisis faktor perlu mengisyaratkan minimal data interval, maka data ordinal tersebut perlu ditingkatkan menjadi data interval. Data ordinal tersebut ditingkatkan skala pengukurannya menjadi skala interval melalui "Method Of Successive Interval" (MSI).

Kedua, membuat matrik korelasi. Semua data yang masuk dan diolah akan menghasilkan matrik korelasi. Matrik korelasi akan mengidentifikasikan variabelvariabel tertentu yang tidak memiliki korelasi dengan variabel yang lain, sehingga dapat dikeluarkan dari analisis. Untuk menguji ketepatan model analisis faktor, maka dapat digunakan Bartlett's test of Sphericity yang dipakai untuk menguji bahwa variabel-variabel dalam sampel berkorelasi. Hasil Bartlett's test of Sphericity menunjukkan apakah hubungan antara variabel-variabel signifikan atau tidak. Statistik lain yang berguna adalah 
pengukuran kelayakan sampel Keiser Meyer Olkin (KMO). Analisis faktor dianggap layak apabila besaran $\mathrm{KMO}$ nilainya minimal 0,50. Besaran ini dipergunakan untuk mengukur derajat korelasi antar variabel dengan kriteria Measure of Sampling Adequacy (MSA) $\geq$ 0,50 .

Ketiga, menentukan jumlah faktor. Variabel disusun kembali berdasarkan pada hasil langkah pada butir dua untuk menentukan faktor yang diperlukan untuk mewakili data. Untuk menentukan berapa faktor yang dapat diterima secara empiris dapat dilakukan berdasarkan besarnya eigenvalue setiap faktor yang muncul. Semakin besar eigenvalue setiap faktor, semakin representatip faktor tersebut untuk mewakili sekelompok variabel. Faktor-faktor ini yang dipilih adalah faktor yang memiliki eigenvalue sama dengan atau lebih dari satu atau (eigenvalue $\geq 1$ ).

Keempat, membuat rotasi faktor. Hasil penyederhanaan faktor dalam matrik faktor menunjukkan hubungan antara faktor dengan variabel individu, tetapi dalam faktor-faktor tersebut terdapat banyak variabel yang berkorelasi sehingga sulit untuk diinterpretasikan. Dengan menggunakan rotasi faktor matrik, matrik faktor ditransformasikan ke dalam matrik yang lebih sederhana mudah untuk diinterpretasikan. Dalam perilaku ini disebut rotasi varimax.

Kelima, interpretasi faktor dilakukan dengan mengelompokkan variabel yang mempunyai faktor loading tinggi ke dalam faktor tersebut. Untuk menginterpretasikan hasil penelitian ini, faktor loading minimal 0,5 . Variabel yang memiliki faktor loading kurang dari 0,5 dikeluarkan dari model.

Keenam, penyelesaian surrogate variable. Mencari salah satu variabel dalam setiap faktor sebagai wakil dari masing-masing faktor. Pemilihan ini didasarkan pada nilai factor loading tertinggi.

Ketujuh, model Fit (ketetapan model). Tahap terakhir dari analisis faktor adalah mengetahui ketetapan dalam memilih teknik analisis faktor antara principal component analysis dan maximum likelihood dengan melihat jumlah residual (perbedaan) antara korelasi yang diamati dengan korelasi yang diproduksi. Semakin kecil persentase nilai residual Root Mean Square Error (RMSE), maka semakin tepat penentuan teknik tersebut. Begitupula sebaliknya semakin besar persentase nilai residual Root Mean Square Error (RMSE), maka semakin tidak tepat penentuan teknik tersebut.

Hipotesis statistik akan dianalisis dengan menggunakan analisis faktor dengan langkah-langkah sebagai berikut.

Pertama, merumuskan masalah dengan menguji matriks korelasi menggunakan menggunakan Barlett's test of Sphericity dengan koefisien KMO yang telah tersedia dalam SPSS 16.0 for Windows. Jika hasil pengujian statistik Barlett's test of Sphericity signifikan dan hasil perhitungan koefisien $\mathrm{KMO}>0,50$ maka persyaratan pengujian analisis faktor untuk menentukan faktor-faktor yang mempengaruhi keputusan pengambilan kredit pada PT. Pegadaian (studi pada PT. Pegadaian (Persero) Cabang Singaraja tahun 2017) bisa dilakukan.

Kedua, untuk menentukan besarnya pengaruh faktor-faktor yang mempengaruhi keputusan pengambilan kredit pada PT. Pegadaian (studi pada PT. Pegadaian (Persero) Cabang Singaraja tahun 2017) dapat dilakukan dengan memilih faktor atau komponen utama yang memiliki parameter akar karakteristik terkecil (eigenvalue) $>1$.

Ketiga, untuk menentukan dimensi atau faktor yang paling mendominasi, maka akan digunakan parameter koefisien varimax rotation dari dimensi atau faktor yang paling mendekati +1 atau mendekati 1.

\section{HASIL DAN PEMBAHASAN}

Faktor-faktor yang mempengaruhi Keputusan Pengambilan Kredit pada PT. Pegadaian (studi pada PT. Pegadaian (Persero) Cabang Singaraja Tahun 2017)

Berikut ini disajikan analisis faktor yang digunakan untuk menganalisis hipotesis statistik dengan memasukkan semua total nilai dari masing-masing dimensi atau faktor terhadap total skor item dari masing-masing dimensi. Analisis faktor menggunakan data interval oleh sebab itu, skor dari masing-masing dimensi terlebih dahulu di transformasi ke dalam data interval kemudian dilakukan penentuan 
matrik korelasi, penentuan jumlah faktor, membuat rotasi faktor, dan menentukan skor masing-masing faktor. Mengukur kecukupan sampel dalam penelitian ini digunakan hasil pengukuran dengan Koefisien Kasier-Meyer-Olkin (KMO) yang bertujuan untuk menguji derajat interkorelasi antara variabel dan ketepatan pemakaian analisis faktor, serta untuk mengetahui kecukupan sampel atau pengukuran kelayakan sampel pada analisis faktor dengan syarat jika nilai KMO $>0,5$ dan uji Bartlett's Test of Sphericity apabila nilai signifikan $<0,05$. Adapun hasil uji KMO dan Bartlett's Test of Sphericity seperti nampak pada tabel 2 berikut ini.

Tabel 2. Hasil untuk Pengujian KMO and B ar l ett's T est of S ph er i ci ty

KMO and Bartlett's Test

Kaiser-Meyer-Olkin Measure of Sampling Adequacy. .542

Bartlett's Test of Sphericity Approx. Chi-Square

10.210

Df

Sig.

Berdasarkan tabel 2 diatas, diperoleh angka KMO and Barlett's Test Of Sphericity sebesar 0,542. Hal ini berarti bahwa jumlah sampel yang digunakan dalam penelitian ini sudah cukup memenuhi syarat dalam melakukan analisis faktor dan metode analisis faktor tepat digunakan untuk menganalisis data yang diperoleh. Hasil pengujian Bartlett's Test of Sphericity menunjukkan hasil penelitian yang signifikan pada taraf nyata 0,017 . Hal ini berarti matrik korelasi memiliki korelasi yang signifikan dengan sejumlah variabel, karena nilai signifikansi lebih kecil dari $\alpha=$ 0,05 .

Pada hasil output Statistic Product and Service Solution (SPPS) for Windows versi 16.0, pengujian Measure of Sampling Adequacy (MSA) dimana tiap variabel dianalisis untuk mengetahui faktor-faktor atau variabel yang layak digunakan dalam analisis faktor. Pada output SPSS (Antiimage Matrices), terdapat kode "a" yang artinya tanda untuk Measure of Sampling Adequacy (MSA).

Faktor yang layak digunakan dalam analisis faktor adalah faktor yang memiliki nilai MSA > 0,50. Apabila terdapat faktor memiliki nilai MSA $<0,50$, maka faktor tersebut dikeluarkan dari model. Hal tersebut dilakukan agar dapat dilakukan analisis faktor. Adapun nilai MSA untuk masing-masing faktor nampak pada tabel 3 berikut

Tabel 3. Hasil Analisis Measure of Sampling Adequacy (MSA)

\begin{tabular}{lc}
\hline \multicolumn{1}{c}{ Faktor } & Nilai MSA \\
\hline Lingkungan & $0,529>0,50$ \\
Organisasi & $0,583>0,50$ \\
Antar-pribadi & $0,540>0,50$ \\
\hline
\end{tabular}

Berdasarkan tabel 3 diatas, dapat diketahui bahwa faktor-faktor dalam penelitian memiliki MSA > 0,50 dan faktor tersebut adalah faktor lingkungan $\left(X_{1.1}\right)$ dengan nilai MSA sebanyak 0,529 , faktor organisasi $\left(X_{1.2}\right)$ dengan nilai MSA sebanyak 0,583 , dan faktor antar-pribadi $\left(X_{1.3}\right)$ dengan nilai MSA sebanyak 0,540. Dengan demikian faktor lingkungan, faktor organisasi, dan faktor antar-pribadi dapat dianalisis secara keseluruhan dan dapat dilanjutkan. Banyaknya faktor yang

Keputusan

Dapat digunakan untuk analisis faktor Dapat digunakan untuk analisis faktor Dapat digunakan untuk analisis faktor mempengaruhi keputusan pengambilan kredit di PT. Pegadaian (studi pada PT. Pegadaian Cabang Singaraja tahun 2017), dapat dijelaskan oleh nilai persentase dari masing-masing faktor. Nilai total variance explained digunakan untuk mengetahui persentase dari tiga faktor yang dianalisis. Adapun faktor-faktor yang dianalisis dalam penelitian ini yaitu faktor lingkungan, faktor organisasi, dan faktor anta-pribadi. Hasil analisis faktor melalui SPSS menunjukkan persentase dari masing-masing faktor dapat dilihat pada tabel 4 berikut ini. 
Tabel 4. Total Variance Explained

\begin{tabular}{|c|c|c|c|c|c|c|}
\hline \multirow[b]{2}{*}{ Component } & \multicolumn{3}{|c|}{ Initial Eigenvalues } & \multicolumn{3}{|c|}{ Extraction Sums of Squared Loadings } \\
\hline & Total & $\%$ of Variance & Cumulative \% & Total & $\%$ of Variance & Cumulative \% \\
\hline 1 & 1.363 & 45.424 & 45.424 & 1.363 & 45.424 & 45.424 \\
\hline 2 & .920 & 30.664 & 76.088 & & & \\
\hline 3 & .717 & 23.912 & 100.000 & & & \\
\hline
\end{tabular}

Extraction Method: Principal Component Analysis.

Berdasarkan tabel 4 diatas, dapat dilihat bahwa faktor lingkungan $\left(X_{1.1}\right)$ memiliki eigenvalue sebesar 1,363 dengan nilai variance sebesar $45,424 \%$, faktor organisasi $\left(\mathrm{X}_{1.2}\right)$ memiliki eigenvalue sebesar 0,920 dengan nilai variance sebesar 30,664\%, dan faktor antar-pribadi $\left(X_{1.3}\right)$ memiliki eigenvalue sebesar 0,717 dengan nilai variance sebesar 23,912\%, Jadi, ketiga faktor-faktor tersebut mempengaruhi keputusan pengambilan kredit di PT. Pegadaian (studi pada PT. Pegadaian Cabang Singaraja tahun 2017). Untuk menjelaskan faktor-faktor yang mempengaruhi keputusan pengambilan kredit pada PT. Pegadaian (studi pada PT. Pegadaian Cabang Singaraja tahun 2017), dapat dilakukan dengan ekstraksi faktor.

Ekstraksi faktor dapat dijelaskan oleh total persentase dari masing-masing faktor utama. Untuk menentukan berapa faktor yang dapat diterima secara empiris dapat dilakukan berdasarkan besarnya eigenvalue setiap faktor yang muncul. Semakin besar eigenvalue setiap faktor, semakin representatip faktor tersebut untuk mewakili sekelompok variabel. Faktor-faktor ini yang dipilih adalah faktor yang memiliki eigenvalue sama dengan atau lebih dari satu atau (eigenvalue $\geq 1$ ). Hal tersebut dapat dilihat pada tabel 5 berikut ini.

Tabel 5. Faktor yang Mempengaruhi Keputusan Pengambilan Kredit pada PT. Pegadaian (Studi pada PT. Pegadaian Cabang Singaraja tahun 2017).

\begin{tabular}{cccc}
\hline Faktor & Eigenvalue & Variance Explained (\%) & Faktor Loading \\
\hline Lingkungan & 1,363 & 45,424 & 0,769 \\
Organisasi & 0,920 & 30,664 & 0,547 \\
Antar-pribadi & 0,717 & 23,912 & 0,678 \\
\hline
\end{tabular}

Berdasarkan tabel 5 diatas, dapat diketahui bahwa ada satu faktor yang memiliki total eigenvalue > 1 yaitu faktor lingkungan. Faktor lingkungan memiliki total eigenvalue sebesar 1,363 dengan nilai variance sebesar 45,424\%. Dengan demikian, $45,424 \%$ dari seluruh variabel yang ada dapat dijelaskan oleh satu faktor yang terbentuk yaitu faktor lingkungan. Faktor lingkungan juga memiliki nilai variance explained lebih besar dari faktor yang lainnya yaitu sebesar $45,424 \%$, berarti hal yang paling pertama kali diperhitungkan apabila nasabah ingin mengambil kredit adalah tingkat permintaan, tingkat suku bunga, tingkat perubahan teknologi, perkembangan politik dan peraturan, perkembangan persaingan, dan perhatian pada tanggung jawab sosial yang dilihat dari PT. Pegadaian (studi pada PT. Pegadaian Cabang Singaraja tahun 2017). Interpretasi faktor dilakukan dengan mengelompokkan variabel yang mempunyai faktor loading tinggi ke dalam faktor tersebut. Untuk menginterpretasikan hasil penelitian ini, faktor loading minimal 0,5 . Mencari salah satu variabel dalam setiap faktor sebagai wakil dari masingmasing faktor. Pemilihan ini didasarkan pada nilai factor loading tertinggi. Langkah selanjutnya adalah menentukan nama faktor yang telah terbentuk untuk masingmasing faktor bersifat subjektif, kadangkala faktor yang memiliki nilai faktor loading tertinggi digunakan untuk memberikan nama faktor. Adapun nilai dari faktor loading dapat dilihat pada tabel 6 berikut ini. 
Tabel 6. Hasil Analisis Rotated Component Matrix

Component Matrix ${ }^{a}$

Component

1

faktor_lingkungan

faktor_antarpribadi

faktor_organisasi

Extraction Method: Principal Component Analysis.

a. 1 components extracted.

Berdasarkan tabel 6 di atas, dapat dikelompokkan menjadi 1 (satu) faktor. Masing-masing faktor tersebut memiliki loading tertinggi disetiap komponen yaitu faktor lingkungan $\left(X_{1.1}\right)$ sebesar 0,769, faktor organisasi $\left(X_{1.2}\right)$ sebesar 0,687 , dan faktor antar-pribadi $\left(X_{1.3}\right)$ sebesar 0,547 .

Faktor yang Paling Dominan Mempengaruhi Keputusan Pengambilan Kredit pada PT. Pegadaian (Studi pada PT. Pegadaian (Persero) Cabang Singaraja Tahun 2017)

Berdasarkan pengujian hipotesis penelitian, untuk menentukan dimensi atau faktor yang paling dominan yang mempengaruhi keputusan pengambilan kredit pada PT. Pegadaian (studi pada PT. Pegadaian Cabang Singaraja tahun 2017), digunakan parameter koefisien varimax mendekati +1 dan -1 . Nilai yang mendekati +1 diawali oleh nilai 0,5 sedangkan nilai yang mendekati -1 diawali oleh $-0,5$. Secara lebih rinci hasil ringkasan rotasi dari matrik faktor memuat nilai varimax rotation, dapat dilihat pada tabel 7 dibawah ini.

Tabel 7. Matriks Rotasi Hasil Analisis

\begin{tabular}{cc} 
Faktor & \\
\hline $\begin{array}{c}\text { Dimensi atau faktor } \\
\text { keputusan } \\
\text { pengambilan kredit }\end{array}$ & $\begin{array}{c}\text { Varimax rotation } \\
(\%)\end{array}$ \\
\hline
\end{tabular}

Lingkungan

$45,424 \%$

Berdasarkan tabel 7 diatas, dapat diketahui bahwa faktor yang paling dominan mempengaruhi adalah faktor lingkungan dengan nilai varimax rotation $45,424 \%$.
Artinya kejelasan dari dimensi atau faktor yang mempengaruhi keputusan pengambilan kredit pada PT. Pegadaian (studi pada PT. Pegadaian Cabang Singaraja tahun 2017) adalah faktor lingkungan sebesar $45,424 \%$.

Merujuk pada hasil penelitian, maka dalam penelitian ini ditemukan tiga faktor yang mempengaruhi keputusan pengambilan kredit pada PT. Pegadaian (studi pada PT. Pegadaian Cabang Singaraja tahun 2017) yaitu, faktor lingkungan, faktor organisasi, dan faktor antar-pribadi. Hal ini sesuai dengan teori yang dinyatakan Kotler (2005:244), "faktorfaktor yang mempengaruhi keputusan pengambilan kredit adalah faktor lingkungan, faktor organisasi, dan faktor antar-pribadi".

Berdasarkan pengujian hipotesis statistik untuk menentukan faktor keputusan pengambilan kredit yang paling dominan maka digunakan parameter varimax rotation dari dimensi atau faktor yang mempengaruhi keputusan pengambilan kredit pada PT. Pegadaian (studi pada PT. Pegadaian Cabang Singaraja tahun 2017) yang paling mendekati +1 atau mendekati - 1. Dari hasil rotasi terhadap faktor matriks pada varimax rotation, maka faktor yang paling mendominasi pada keempat komponen utama yang terbentuk yaitu, faktor lingkungan dengan nilai variance rotation sebesar $45,424 \%$. Sehingga dapat disimpulkan bahwa faktor yang mendominasi keputusan pengambilan kredit pada PT. Pegadaian (studi pada PT. Pegadaian Cabang Singaraja tahun 2017) adalah faktor lingkungan.

Hasil penelitian ini sesuai dengan pengertian faktor lingkungan menurut 
(Kotler, 2005:244) merupakan faktor yang diberikan perhatian khusus oleh nasabah. Hal tersebut disebabkan karena faktor lingkungan menyangkut tentang keadaan ekonomi masyarakat yang sedang berlangsung dan yang akan berlangsung, seperti tingkat permintaan masyarakat akan barang dan jasa untuk memenuhi kebutuhan hidupnya, tingkat bunga atau tingkat suku bunga yang berlaku di setiap lembaga keuangan, tingkat perubahan teknologi, perkembangan politik dan peraturan, perkembangan persaingan, dan perhatian pada tanggung jawab sosial dalam mengambil kredit. Selain itu, dengan adanya tingkat tingkat perubahan teknologi yang terus berkembang maka secara tidak langsung konsumen diharapkan mampu mengikuti perubahan perkembangan tersebut guna memudahkan dalam melakukan transaksi dalam hal pengambilan kredit. Para nasabah secara aktif memantau dan memperhatikan tingkat suku bunga kredit yang berlaku di PT. Pegadaian dengan membandingkan tingkat suku bunga kredit di lembaga keuangan lainnya guna memilih tingkat suku bunga yang sesuai dengan kemampuannya.

\section{SIMPULAN DAN SARAN Simpulan}

Berdasarkan hasil analisis data dan pembahasan, maka dapat ditarik simpulan sebagai berikut. Faktor-faktor yang mempengaruhi keputusan pengambilan kredit pada PT. Pegadaian (studi pada PT. Pegadaian Cabang Singaraja tahun 2017) yaitu sebanyak tiga faktor. Faktor-faktor tersebut diantaranya faktor lingkungan yang memiliki eigenvalues sebesar 1,363 dengan nilai variance sebesar $45,424 \%$, faktor organisasi yang memiliki eigenvalues sebesar 0,920 dengan nilai variance sebesar $30,664 \%$, dan faktor antar-pribadi yang memiliki eigenvalues sebesar 0,717 dengan nilai variance sebesar $23,912 \%$.

Berdasarkan hasil penelitian diatas, maka faktor yang paling dominan mempengaruhi keputusan pengambilan kredit pada PT. Pegadaian (pada di PT. Pegadaian Cabang Singaraja tahun 2017) adalah faktor lingkungan sebesar 45,424\%.

\section{Saran}

Berdasarkan pembahasan dan simpulan di atas, maka dapat diajukan beberapa saran sebagai berikut.

Bagi pihak PT. Pegadaian (Persero) Cabang Singaraja diharapkan mampu mempertahankan bahkan meningkatkan kualitas pelayanan terutama pada faktor lingkungan dengan cara melakukan peningkatan citra kepada masyarakat secara spontan, sehingga masyarakat tahu dan paham akan produk yang ada di PT. Pegadaian. Sedangkan faktor organisasi dan faktor antar-pribadi juga harus ditingkatkan. Faktor organisasi dapat ditingkatkan dengan cara merekrut karyawan marketing yang akan memberikan pemahaman produk kepada masyarakat, serta faktor antar-pribadi dapat ditingkatkan dengan cara memberikan perhatian penuh kepada nasabah pada saat melakukan transaksi, sehingga nasabah tersebut merasa puas dengan pelayanan di PT. Pegadaian dan nantinya diharapkan nasabah tersebut mampu memberikan pengaruh yang postif terhadap masyarakat lainnya untuk bisa memutuskan mengambil kredit di PT. Pegadaian.

Bagi peneliti selanjutnya, Peneliti selanjutnya dapat meneruskan penelitian ini dengan meneliti lebih lanjut kesimpulan yang dihasilkan dari penelitian ini dan peneliti selanjutnya sebaiknya dapat mengambil responden dari Cabang PT. Pegadaian lainnya dengan jumlah populasi yang lebih beragam lagi.

\section{DAFTAR PUSTAKA}

Indriantoro, Nur., \& Bambang, Supomo. 2009. Metodologi Penelitian Bisnis untuk Akuntansi dan Manajemen. Yogyakarta: BPFE

Kotler, Philip. 2005. Manajemen Pemasaran. Terjemahan Molan Benyamin. Marketing Management. Jilid 1. Edisi Kesebelas. Jakarta: PT. INDEKS Kelompok Gramedia.

Prasetyo, Bambang., \& Lina, Miftahul, Jannah. 2016. Metode Penelitian Kuantitatif: Teori dan Aplikasi. Jakarta: Rajawali Pers. 
Sarwono, Jonathan., \& Ely, Suhayati. 2010. Riset Akuntansi Menggunakan SPSS. Yogyakarta: Graha Ilmu.

Setiadi, J. Nugroho. 2003. Perilaku Konsumen: Konsep Implikasi Untuk Strategi dan enelitian Pemasaran. Jakarta: Prenada Media Group.

-------. 2008. Business Economics And Managerial Decision Making. Jakarta: Prenada Media Group.

Suarni, Gusti, Ayu, Putu. 2014. Analisis Faktor-Faktor yang Mempengaruhi Keputusan Nasabah dalam

Pengambilan Kredit pada Lembaga Perkreditan Desa (LPD) Desa Pakraman Manggissari. Skripsi tidak diterbitkan. Universitas Pendidikan Ganesha. Singaraja: Universitas Pendidikan Ganehsa.

Sugiyono. 2014. Metode Penelitian Bisnis. Bandung: CV. Alfabeta

Suliyanto. 2005. Analisis Data dalam Aplikasi Pemasaran. Bogor: Ghalia Indonesia.

Umar, Husein. 2003. Business And Introduction. Jakarta: PT. Gramedia Pustaka Utama.

------. 2005. Business And Introduction. Jakarta: PT. Gramedia Pustaka Utama.

Yasa, I, Gusti, Ngurah. Kardi. 2015. FaktorFaktor yang Mempengaruhi Keputusan Nasabah dalam Mengambil Kredit pada PT. Finansia Multi Finance (Kredit Plus) Pos Singaraja. Skripsi tidak diterbitkan urusan Pendidikan Ekonomi. Universitas Pendidikan Ganesha. Singaraja: Universitas Pendidikan Ganesha. 